\title{
ВАРИАНТЫ АЛЛЕЛЬНОГО ПОЛИМОРФИЗМА (ТТТА)N-ПОВТОРОВ ГЕНА АРОМАТАЗЫ (СУР19) У ЛИЦ ЖЕНСКОГО ПОЛА, ИСПЫТЫВАЮЩИХ ГЕНДЕРНУЮ ДИСФОРИЮ
}

\author{
${ }^{1}$ Кременицкая С.А., ${ }^{1}$ Соловьева Н.В., ${ }^{2}$ Вильянов В.Б., ${ }^{3}$ Кичук И.В., ${ }^{1,4}$ Макарова Е.В. \\ ${ }^{1}$ Научный чентр персонализированной психиатрии \\ ${ }_{2}^{2}$ «Федеральный центр цереброваскулярной патологии и инсульта» Минздрава России, Москва \\ ${ }^{3}$ ФГБОУ ВО «РНИМУ им. Н.И. Пирогова», Москва \\ ${ }^{4}$ ФГБУ «НМИЦ реабилитачии и курортологии» Минздрава России, Москва
}

Гендерная дисфория (ГД) это ощущение дискомфорта от своего биологического и/или социального пола, зачастую сопровождающееся желанием подвергнуться хирургическому вмешательству или получить гормональное лечение. Для этого состояния по МКБ-10 используют код F64.0 Транссексуализм. Для описания лица женского пола, желающего сделать переход в мужской пол, используют термин FtM — female-to-male transsexual.

ЦЕЛЬ: изучение аллельного полиморфизма (ТTТА)n-повторов гена ароматазы (СҮР19) у российской выборки FtM.

МАТЕРИАЛЫ И МЕТОДЫ: Исследование проводилось на пациентах FtM с Установленным диагнозом F.64.0 ( $n=169$, средний возраст 24,1) и контрольной выборке женщин без ГД ( $n=127$, средний возраст 21,2). Общая выборка была разбита по степени выраженности ГД на: «ядерную» $(\mathrm{n}=77)$, «переходную» $(\mathrm{n}=79)$ и «краевую» $(n=13)$.

Геномная ДНК из проб слюны выделялась с помощью набора DiatomTM DNA Prep200 (Лаборатория Изоген). Анализ полиморфных вариантов осуществляли методом локус специфичной полимеразной цепной реакции с меченными праймерами. Фрагментный анализ продуктов амплификации проводили на приборе Applied Biosystems 3100. Результаты анализировали с помощью программы Peak Scanner Software v.1.0. Статистический анализ результатов проводился с помощью программы Statistica 7.

PEЗУЛЬтАTЫ: у 76,33\% пациентов FtM в анамнезе отмечалась депрессия, у 27,22\% аутоагрессия, 7,1\% совершали суицидальные попытки. В «ядерной» группе средний возраст составил 23,3, в «переходной» - 24,2 и в «краевой» - 28,1 год. Первые признаки ГД в «ядерной» группы отмечались с 8,5 лет, в «переходной» с 10 и в «краевой» с 13,3 лет. Депрессивные нарушения выявлены у 70,13\% пациентов в «ядерной», 78,48\% в «переходной» и 100\% в «краевой» группах. Максимальные значения аутоагрессии и суицидальных попыток выявлены в «ядерной» группе (29,87 и 12,99\% соответственно), промежуточные в «переходной» (25,32 и 2,53\%) и наименьшие в «краевой» $(23,08 \%$ и 0$)$.

Фрагментный анализ повторов (ТTТА)n гена ароматазы в исследованных выборках выявил 9 аллельных вариантов, содержащих 6-14 повторов (R), в контрольной группе отсутствовал аллель 6R. В обеих выборках преобладают 7-9R и 12R аллели. Сравнительный анализ частот распределения аллелей показал достоверные различия между общей группой FtM, а также объединенной «ядерной» и «переходной» группой, и контрольной выборкой ( $p=0,007$ и $p=0,016$ соответственно). Анализ частот распределения $S$ или $L$ аллелей показал достоверные различия между пациентами «ядерной» и контрольной группы. $\mathrm{B}$ «ядерной» группе $S$ аллельные варианты встречались чаще (0.597 и 0.508 соответственно; $\mathrm{p}=0,039)$, также, в 2 раза чаще встречался гомози-

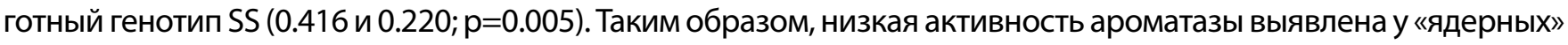
транссексуалов. Клинически более мягкие случаи течения ГД и «краевые» формы характерны для пациентов с более высоким значением (ТTТА)n повторов. Более активная ароматаза (и более активный процесс ароматизации тестостерона в эстрадиол) не сопровождалась суицидальной активностью и аутоагрессией.

ВЫвОДы: выявлена связь между количеством (ТTТА)n повторов в гене (СҮР19) и степенью выраженности клинических проявлений ГД, что подтверждает целесообразность разделения выборки на «ядерную», «переходную» и «краевую» группы. B «ядерной» группе FtM чаще встречаются $\mathrm{S}$ аллельные варианты и в два раза выше наблюдается гомозиготный генотип SS, чем в контрольной группе женщин без ГД. 